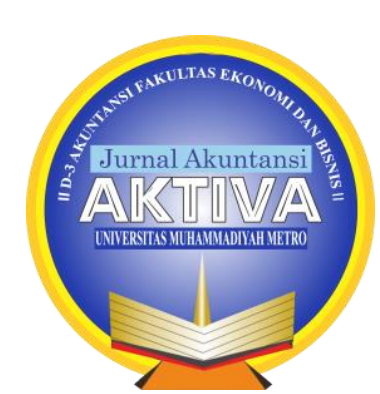

Jurnal Akuntansi AKTIVA, Vol 1, No 1, April 2020

\title{
DIREKSI PEREMPUAN DAN PENGARUHNYA PADA LIKUIDITAS PASAR SAHAM
}

\author{
${ }^{1 *}$ Heri Susanto, ${ }^{2}$ Hestin Mutmainah, ${ }^{3}$ Ida Ayu Kade Rachmawati \\ ${ }^{1} \mathrm{AA}$ YKPN, Yogyakarta \\ ${ }^{2,3}$ STIE Surakarta \\ Email: ${ }^{1}$ herisusanto303@gmail.com, ${ }^{2}$ hestin1712@gmail.com, ${ }^{3}$ kade.rachmawati@gmail.com
}

\begin{abstract}
This study aims to analyze the phenomenon of emancipation in the current era of modernity. There have been many studies relating to gender issues in accounting and finance. But this research is different from previous research, we examine how women directors can influence stock and investor trading according to their position on the board of directors. To better assess the influence of female members, we take into account the endogeneity issues that can arise between corporate governance and stock liquidity. To our knowledge, this study is the first study that distinguishes between the effects of female directors on investor decisions, according to their position on the board of directors whether they are on the board of directors or as an independent member. The initial step of this research is to collect data relating to the object that will be used as a sample, namely manufacturing company data with the food and beverage sub sector in Indonesia in 2017-2019. Next will be observing and tabulating data as a means to obtain data to be processed and analyzed using regression analysis techniques. Based on the results of the regression found that female directors and corporate governance have a positive effect on stock liquidity.
\end{abstract}

Keywords: Women, Board of Directors, Market Reaction, Corporate Governance, Stocks

\begin{abstract}
ABSTRAK
Penelitian ini bertujuan untuk menganalisis fenomena emansipasi di era modernitas saat ini. Penelitian-penelitian yang berkaitan dengan isu gender dalam akuntansi dan keuangan sudah banyak dilakukan. Tetapi penelitian ini berbeda dengan penelitian sebelumnya, kami menguji bagaimana direksi perempuan dapat mempengaruhi perdagangan saham serta investor sesuai dengan posisi mereka di dewan direksi. Untuk menilai pengaruh anggota perempuan dengan lebih baik, kami memperhitungkan masalah endogenitas yang dapat muncul antara tata kelola perusahaan dan likuiditas saham. Sepengetahuan kami, penelitian ini merupakan penelitian pertama yang membedakan antara efek direktur wanita pada keputusan investor, sesuai dengan posisi mereka di dewan direksi apakah mereka berada di dalam direksi maupun sebagai anggota independen. Langkah awal dari penelitian ini adalah mengumpulkan data-data yang berhubungan dengan obyek yang akan digunakan sebagai sample yaitu data Perusahaan manufaktur dengan sub sektor makanan dan minuman yang ada di Indonesia tahun 2017-2019. Selanjutnya akan melakukan observasi dan tabulasi data sebagai sarana untuk memperoleh data yang akan diolah dan dianalisis dengan menggunakan teknik analisis regresi. Berdasarkan hasil regresi ditemukan bahwa direksi perempuan dan corporate governance berpengaruh positif terhadap likuiditas saham.
\end{abstract}

Kata Kunci: Perempuan, Dewan Direksi, Reaksi Pasar, Tata Kelola Perusahaan, Saham 


\section{PENDAHULUAN}

Terlepas dari perdebatan sengit tentang kehadiran perempuan di dewan direksi perusahaan, Terjesen et al. (2015) menunjukkan bahwa perempuan mewakili 10, 3 persen dari dewan direksi di 67 negara. Pangsa manajerial perempuan secara keseluruhan pekerjaan adalah antara 20 persen dan 40 persen di 48 dari 63 negara (ILO, 2017). Di Indonesia, perempuan mewakili hampir 17 persen keterwakilan perempuan dalam pemilihan anggota dewan.(Badan Pusat Statistik, 2019).

Pada literatur akademik, banyak penelitian telah dilakukan untuk menjelaskan dan menganalisis pengaruh keragaman gender dalam perusahaan, khususnya pada dewan direksi. Di satu sisi, telah dikemukakan bahwa anggota perempuan dapat memiliki efek positif pada kinerja keuangan dan sosial (Alazzani et al., 2017).

Pada beberapa penelitian, keragaman gender dianggap sebagai alat tata kelola yang dapat meningkatkan kualitas tata kelola, transparansi, pemantauan, dan perlindungan hak-hak pemegang saham (Foo dan Zain, 2010). Keterwakilan perempuan dipandang sebagai sinyal kualitas tata kelola yang tinggi (OECD, 2014).

Penelitian ini berkontribusi pada literatur tentang efek dewan direksi perempuan pada lingkungan perusahaan, khususnya pada keputusan investor. Terlepas dari fakta bahwa ada seruan yang meningkat untuk lebih banyak adanya keragaman dewan direksi dalam perusahaan, studi tentang bagaimana pembuat kebijakan pasar dan investor mempertimbangkan reaksi terhadap upaya perusahaan dalam pengertian khusus, jarang terjadi (Ahmed dan Ali, 2017; Abad et al. 2017; Ismail dan Manaf, 2016; Gregory et al. 2013). Sebagian besar penelitian ini menyimpulkan bahwa penunjukan perempuan sebagai direktur dapat dipandang sebagai sinyal positif oleh perusahaan kepada para pemangku kepentingan (Ahmed dan Ali, 2017; Abad et al. 2017; dan Ismail dan Manaf, 2016).

Berbeda dengan penelitian sebelumnya, kami menguji bagaimana direksi perempuan dapat mempengaruhi perdagangan investor sesuai dengan posisi mereka di dewan direksi. Untuk menilai pengaruh anggota perempuan dengan lebih baik, kami memperhitungkan masalah endogenitas yang dapat muncul antara tata kelola perusahaan dan likuiditas saham.

Sepengetahuan kami, ini adalah penelitian ini merupakan penelitian pertama yang membedakan antara efek direktur wanita pada keputusan investor, sesuai dengan posisi mereka di dewan apakah mereka berada di dalam dan anggota independen. Sejauh yang kami tahu, penelitian ini merupakan penelitian pertama yang membedakan antara efek direktur wanita pada keputusan investor, sesuai dengan posisi mereka di dewan direksi apakah mereka berada di dalam direksi maupun sebagai anggota direksi independen. 


\section{LANDASAN TEORI}

\subsection{Teori eselon}

Dalam teori eselon atas (Hambrick dan Mason, 1984), dikemukakan bahwa karakteristik demografis dari tim manajemen puncak adalah penentu signifikan dari pilihan strategis perusahaan. Secara khusus, profil eksekutif, khususnya pengalaman, nilai-nilai dan sifat-sifat kepribadian mereka membentuk proses pengambilan keputusan dan bagaimana mereka mengumpulkan informasi dan menangani kontingensi lingkungan (Hambrick, 2007).

Ada banyak penelitian tentang gender sebagai proksi untuk kerangka kognitif dewan direksi. Beberapa penelitian berpendapat bahwa direksi wanita membawa keterampilan dan pengetahuan khusus karena mereka memiliki pengalaman dan latar belakang yang berbeda dari rekan-rekan pria. Pengangkatan direktur wanita mengarah ke pilihan yang berbeda (Terjesen et al., 2009; Singh et al., 2008; dan Singh dan Vinnicombe, 2004).

\subsection{Teori legitimasi}

Sebagai contoh, Singh dan Vinnicombe (2004) berpendapat bahwa keragaman gender menjadi bentuk legitimasi yang berharga yang menyoroti dan menandakan kehadiran peluang karir yang lebih baik. membantu untuk menarik karyawan yang berkualitas dari kumpulan pelamar yang lebih luas (Rose, 2007). Mengingat bahwa wanita memiliki pengalaman dan lintasan karier yang berbeda dibandingkan dengan anggota pria mereka, modal manusia dan sosial yang sangat beragam dapat berkontribusi pada kinerja yang lebih baik (Singh et al., 2008).

Selain itu, heterogenitas dalam dewan memastikan kekuatan yang seimbang dalam mengambil keputusan (Ueng et al. 2009; dan Peterson dan Philpot, 2007). Bahkan, sangat diperdebatkan bahwa wanita lebih menghindari risiko daripada pria (Croson, dan Gneezy, 2009). Dengan demikian, keragaman gender dalam dewan perusahaan dapat mengurangi kemungkinan pengambilan risiko yang berlebihan (lihat antara lain Sghaier, dan Hamza, 2018, Faccio et al. 2016; Loukil dan Yousfi, 2016; Cosentino et al. 2012; dan Jianakoplos dan Bernasek 1998). Oleh karena itu, meningkatkan keragaman gender di dewan perusahaan dapat melindungi kepentingan pemegang saham dengan lebih baik, terutama kepentingan pemegang saham minoritas.

\subsection{Teori agency}

Menurut teori agensi, perusahaan dengan persentase yang lebih besar dari direktur perempuan dapat menanggung biaya agensi yang lebih rendah, terutama di perusahaan yang diatur dengan buruk (lihat antara lain Jurkus et al. 2011; Francoeur dan Sinclair-Desgagné, 2008; Farrell et al. 2005 dan Arfken et al. 2004). Gul et al. (2011) berpendapat bahwa keragaman gender di dewan meningkatkan kualitas tata kelola perusahaan karena meningkatkan pemantauan atas manajer dan mengubah komunikasi dan diskusi dalam rapat dewan. 
Studi komite dewan menunjukkan bahwa direktur wanita paling sering bertugas di komite tertentu: mereka menghadapi penghalang di ruang dewan direksi sementara mereka seharusnya mencapai posisi manajemen puncak (Smith dan Parrotta, 2018). Misalnya, mereka dapat dengan mudah bergabung dengan komite audit, CSR, dan tata kelola perusahaan sementara mereka tidak mungkin ditunjuk untuk komite strategis,

Dalam penelitian terbaru, Bugeja et al. (2016) menggarisbawahi bahwa ketika wanita duduk di komite ini, gaji CEO; bonus dan total kompensasi berkurang. Kehadiran mereka dalam komitekomite ini dapat mengarah pada peningkatan transparansi. Akibatnya, keragaman gender di dewan dapat dianggap sebagai mekanisme pengganti untuk pemerintahan di perusahaan-perusahaan yang dikelola dengan buruk.

\subsection{Gender}

Hastuti (2007) mendefinisikan gender lebih dari sekedar pembedaan laki-laki dan perempuan dilihat dari konstruksi sosial budaya, tetapi lebih menekankan pada konsep analitis yang digunakan untuk menjelaskan sesuatu. Pada sebagian besar organisasi perbedaan gender masih mempengaruhi kesempatan dan kekuasaan. Perbedaan tersebut dapat menyebabkan diskriminasi gender dalam pekerjaan. Hal ini dapat menurunkan kinerja serta prospek karier seorang wanita karena adanya kesempatan yang terbatas dalam peningkatan kemampuan dan pengembangan hubungan kerja (Praditaningrum, 2012). Perspektif gender menurut (Palmer, 1997)dapat dilihat pertama, dari sudut equity model dan complementary contribution model, atau kedua dari sudut stereotype yaitu Sex Role Stereotypes dan Managerial Stereotypes.

\subsection{Good Corporate Governance (GCG)}

Tata kelola perusahaan yang baik (CG) memastikan bahwa lingkungan bisnis itu adil dan transparan dan perusahaan bertanggung jawab atas tindakan mereka (Larcker et al., 2007). Oleh karena itu, minat dalam aspek manajemen bisnis ini diungkapkan oleh luas literatur tentang topik ini. Apakah atau tidak mekanisme ini berperan dalam peningkatan kegiatan keuangan dan posisi suatu perusahaan, mereka telah menarik bagi beberapa orang peneliti. Terutama, Shleifer dan Vishny (1997) menggarisbawahi "sangat praktis pentingnya "CG (hlm. 737). Oleh karena itu, komentar mereka menekankan salah satu banding melakukan penelitian di bidang ini: hubungannya langsung dengan praktik perusahaan. CG peneliti memiliki pandangan unik untuk secara langsung menginspirasi praktik CG melalui tindakan hati-hati penggabungan teori dan studi pengalaman, terutama pada inkonsistensi antara kepemilikan dan kontrol dan penyimpangan dari aturan satu suara satu suara yang diinginkan (La Porta et al., 1998).

\subsection{Penelitian Terdahulu}

Dalam beberapa penelitian yang pernah dilakukan berkaitan dengan penelitian yang akan dilakukan mengenai Direksi Perempuan dan Pengaruhnya Pada Likuiditas Pasar Saham sebagai berikut : 
2.6.1 Gregory et al. (2013) menguji respon pasar saham jangka pendek dan jangka panjang terhadap gender direktur. Mereka mengamati bahwa bias gender menghilang dalam jangka panjang dan pasar saham, akhirnya, bereaksi positif terhadap direktur eksekutif wanita.

2.6.2 Di negara berkembang, investor Singapura umumnya merespons positif pengangkatan direktur perempuan dan lebih reseptif ketika adanya perempuan pada jabatan direktur independen (Kang et al. 2010).

2.6.3 Di perusahaan Malaysia, Ismail dan Manaf (2016) menemukan efek positif pada abnormal return, terlihat pada hari sebelum pengangkatan direktur perempuan dan pada abnormal return rata-rata kumulatif selama periode berikutnya (1-10 hari). Selain itu, mereka mengemukakan bahwa beberapa atribut, seperti usia muda, dan tidak memiliki hubungan internasional atau afiliasi keluarga dengan direktur lain, mengarah pada hasil yang lebih signifikan.

2.6.4 Ahmed dan Ali (2017) menganalisis peran direksi perempuan pada pasar Australia menggunakan metode ordinary least square (OLS) yang mengabaikan masalah endogenitas antara variabel penjelas dan variabel yang dijelaskan, khususnya ketika menyangkut tata kelola.

2.6.5 Nekhili et al. (2016)Kehadiran perempuan sebagai dewan direksi dapat mengurangi konflik keagenan antara pemegang saham mayoritas dan minoritas dan antara pemegang saham dan manajer.

Berbeda dengan penelitian sebelumnya, kami menguji bagaimana direktur perempuan mampu mempengaruhi perdagangan investor sesuai dengan posisi mereka di dewan direksi. Untuk menilai pengaruh anggota perempuan dengan lebih baik, kami memperhitungkan masalah endogenitas yang dapat muncul antara good corporate governance dan likuiditas saham. Sejauh yang kami tahu, penelitian ini merupakan penelitian pertama yang membedakan antara efek direktur wanita pada keputusan investor, sesuai dengan posisi mereka di dewan direksi apakah mereka berada di dalam direksi maupun sebagai anggota direksi independen.

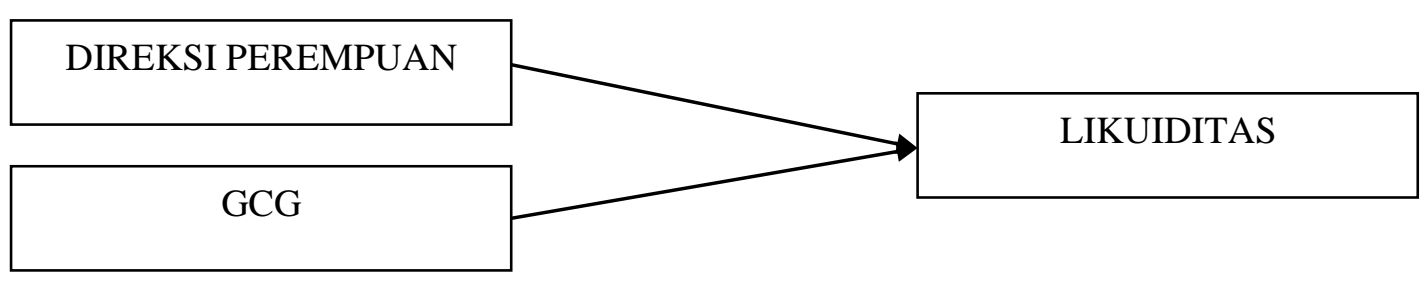

Gambar 1. Kerangka Pemikiran 


\subsection{Hipotesis Penelitian}

$\mathrm{H}_{1}$ : Apakah kehadiran direksi perempuan di dewan meningkatkan likuiditas pasar saham.

$\mathrm{H}_{2}$ : Apakah good corporate governance dan likuiditas pasar saham berhubungan positif.

\section{METODE PENELITIAN}

Penelitian mengambil sampel perusahaan manufaktur dengan sub sektor makanan dan minuman yang ada diindonesia yang listing di bursa efek Indonesia tahun 2017- 2019 untuk menjadi obyek dalam perolehan data. Data yang diperoleh dari bursa efek Indonesia yang telah dikembalikan akan dibuat tabulasi data dengan menggunakan program excel. Pengolahan data dengan menggunakan SPSS yang hasilnya kemudian akan dianalisis dan selanjutnya akan dilakukan pembahasan. Kesimpulan dan saran jika ada akan dibuat untuk meringkas hasil penelitian yang telah dilakukan.

\subsection{Variabel Operasional}

Dalam penelitian ini variabel independen yang digunakan adalah dewan direksi perempuan diukur dengan Variabel dummy dengan 1 jika ada setidaknya seorang wanita di dewan direksi, dan 0 sebaliknya.dan good corporate governance diukur dengan CGPI Index. Likuiditas menjadi variabel dependen diukur dengan rasio likuiditas.

\subsection{Model Yang Digunakan}

Dalam penelitian ini akan menggunakan metode statistik untuk menguji hipotesis yang akan dibuktikan yaitu menggunakan regresi berganda (multiple regression) dengan model persamaan sebagai berikut :

$$
\text { Liquidity }_{i t}=\beta_{0}+\beta_{1} \text { Gender }_{i t}+\beta_{2} \text { Governance }_{i t}+\mathrm{e}
$$

Keterangan :

$$
\begin{aligned}
& \mathrm{Y}: \text { Liquidity } \\
& \mathrm{X}_{1}: \text { gender (dewan direksi perempuan) } \\
& \mathrm{X}_{2}: \text { Governance }(\mathrm{GCG}) \\
& \beta \quad: \text { Koefisien Regresi } \\
& \mathcal{E}: \text { Error }
\end{aligned}
$$

Dalam penelitian ini yang digunakan sebagai variabel bebas dalam penelitian ini Variabelvariabel bebasnya $(\mathrm{X})$ adalah :

$\mathrm{X} 1=$ dewan direksi perempuan

$\mathrm{X} 2=$ good corporate governance 
Sedangkan untuk variabel terikatnya (Y) adalah Liquidity.

\subsection{Teknik Pengumpulan Data}

Pendekatan dalam penelitian ini adalah pendekatan kuantitatif, menggunakan metode pengumpulan data dokumentasi. Penelitian ini disajikan dengan angka-angka. Penelitian kuantitatif adalah pendekatan penelitian yang banyak dituntut menguakan angka, mulai dari pengumpulan data, penafsiran terhadap data tersebut, serta penampilan hasilnya.

\subsection{Teknik Analisis Data}

Data akan dianalisis dengan menggunakan analisis regresi linier berganda. Untuk pengujian hipotesa akan menggunakan pengujian dengan uji t dan juga uji F. Sedangkan untuk mengukur besar kemampuan menerangkan dari variable independen terhadap variabel dependen dalam suatu model regresi akan dilakukan pengukuran Koefisien Determinasi.

\section{HASIL DAN PEMBAHASAN}

\subsection{Pengujian Deskriptif}

Hasil pada Tabel memberikan estimasi persamaan menggunakan regresi. Kami hanya melaporkan hasil yang signifikan. Hasil pengolahan statistik deskriptif berupa nilai rata-rata (mean), standar deviasi, varians, nilai maksimum dan nilai minimum ditampilkan pada tabel berikut:

Tabel 1

Hasil Uji Deskriptif

\begin{tabular}{|c|c|c|c|c|c|}
\hline & $\mathrm{N}$ & Minimum & Maximum & Mean & $\begin{array}{l}\text { Std. } \\
\text { Deviation }\end{array}$ \\
\hline Likuiditas Saham & 78 & 16,05 & 26,33 & 23,2848 & 1,98254 \\
\hline CGPI Score & 78 & 74,88 & 98,86 & 86,4845 & 4,66678 \\
\hline Gender & 78 & 0.00 & 1.00 & 0.76 & 0.43 \\
\hline Valid N (listwise) & 78 & & & & \\
\hline
\end{tabular}

Sumber: Data Diolah (2020)

Berdasarkan tabel di atas diketahui bahwa nilai minimum dan maksimum untuk likuiditas saham adalah sebesar 16,05 dan 26,33 dengan nilai rata-rata sebesar 22,28 serta standar deviasi sebesar 1,98. Nilai minimum dan maksimum untuk nilai CGPI adalah sebesar 74,88 dan 98,86 dengan nilai rata-rata sebesar 86,48 serta standar deviasi sebesar 4,6. Nilai minimum dan maksimum untuk Gender adalah sebesar 0,00 dan 1,00 dengan nilai rata-rata sebesar 0,76 serta standar deviasi sebesar 0,43 .

\subsection{Pengujian Hipotesis}

Hasil pada Tabel memberikan estimasi persamaan menggunakan regresi. Kami hanya melaporkan hasil yang signifikan ditampilkan pada tabel berikut: 
Tabel 2. Hasil Pengujian Analisis Regresi Linear Berganda

\begin{tabular}{|c|c|c|c|c|c|}
\hline \multirow[b]{2}{*}{ Model } & \multicolumn{2}{|c|}{$\begin{array}{c}\text { Unstandardized } \\
\text { Coefficient }\end{array}$} & \multicolumn{2}{|c|}{$\begin{array}{l}\text { Standardized } \\
\text { Coefficients }\end{array}$} & \multirow[b]{2}{*}{ Sig. } \\
\hline & B & Std.Error & $\mathrm{B}$ & $\mathrm{T}$ & \\
\hline $\begin{array}{l}1 \text { (Constant) } \\
\text { Likuiditas }\end{array}$ & 27,04 & 19,74 & & 1,37 & 0,173 \\
\hline Saham & 0,751 & 0,956 & 0,071 & 0,786 & 0,434 \\
\hline CGPI Score & .393 & .796 & .041 . & 493 & .623 \\
\hline Gender & 5,979 & 2,047 & 0,269 & 2,92 & 0,004 \\
\hline
\end{tabular}

Mengenai keragaman gender, jumlah dari perempuan yang ditunjuk untuk posisi dewan direksi secara signifikan terkait dengan variabel likuiditas mengurangi masalah likuiditas dan meningkatkan volume perdagangan harian yang menyiratkan bahwa pasar menerima kehadiran direksi perempuan di perusahaan. Karenanya, kami tidak dapat menolak H1. Temuan ini dikuatkan dengan orang-orang Ahmed dan Ali (2017) dan Abad et al. (2017) yang berpendapat bahwa menunjuk anggota perempuan ke ruang dewan dapat menarik investor dan meningkatkan likuiditas pasar saham.

Hasil dari pengujian hipotesis ini adalah variabel nilai CGPI secara parsial berpengaruh terhadap likuiditas saham. Hasil penelitian ini sejalan dengan penelitian yang dilakukan oleh Prommin et al. (2014) meneliti pengaruh corporate governance terhadap likuiditas di Thailand. Penelitian ini menunjukkan bahwa tata kelola yang efektif dapat meningkatkan keuangan dan operasional yang transparansi, sehingga dapat mengurangi adverse selection.

\section{SIMPULAN DAN SARAN}

Untuk menilai pengaruh dewan direksi perempuan terhadap likuiditas pasar saham, penelitian ini menganalisis hubungan antara tata kelola perusahaan, likuiditas pasar saham, dan keragaman gender. Hasil memberikan bukti bahwa perdagangan investor menerima penunjukan direktur wanita yang meningkatkan likuiditas pasar saham dengan mengurangi biaya likuiditas dan meningkatkan volume perdagangan harian.

Penelitian ini berkontribusi pada perdebatan saat ini tentang manfaat akses perempuan ke posisi pengambilan keputusan, seperti posisi direktur, dari sudut pandang pasar. Pertanyaan tentang bagaimana investor bereaksi terhadap pengangkatan anggota wanita belum sepenuhnya dieksplorasi. Hal ini menunjukkan bahwa direktur wanita dapat menghasut investor untuk memperdagangkan lebih banyak saham sementara menunjuk yang independen mengurangi biaya perdagangan mereka. Dalam penelitian masa depan, akan menarik untuk menganalisis profil direksi perempuan dan laki-laki dari perspektif yang lain. 


\section{REFERENSI}

Ahmed, A., and Ali, S. (2017). Boardroom gender diversity and stock liquidity: Evidence from Australia. Journal of Contemporary Accounting \& Economics, 13(2), 148-165.

Alazzani, A., Hassanein, A. and Aljanadi, Y.,( 2017). Impact of gender diversity on social and environmental performance: evidence from Malaysia. Corporate Governance: The International Journal of Business in Society, 17(2), 266-283.

Abad, D., Lucas-Pérez, M. E., Minguez-Vera, A., and Yagüe, J. (2017). Does gender diversity on corporate boards reduce information asymmetry in equity markets?. BRQ Business Research Quarterly 20, 192-205.

Foo, Y. B., \& Zain, M. M. (2010). Board independence, board diligence and liquidity in Malaysia: A research note. Journal of Contemporary Accounting \& Economics, 6(2), 92-100.

Gregory, A., Jeanes E., Tharyan R., and Tonks I. 2013. Does the stock market gender stereotype corporate boards? Evidence from the market's reaction to directors" trades. British Journal of Management 24(2), 174-190.

Hambrick, D. C., and Mason, P. A. (1984). Upper echelons: The organization as a reflection of its top managers. Academy of Management Review, 9(2), 193-206.

Hambrick, D. C., (2007). Upper echelons theory: An update. Academy of Management Review, 32(2), 334-343.

Ismail, K.N.K, and Manafe, K.B.A. (2016). Market reactions to the appointment of women to the boards of Malaysian Firms, Journal of Multinational Financial Management, 36, 75-88.

Loukil, N. and Yousfi O. (2016). Does gender diversity on corporate boards increase risk-taking? Canadian Journal of Administrative Sciences 33 (1), 66-81.

Nekhili, M., Chakroun, H., \& Chtioui, T. (2016). Women's Leadership and Firm Performance: Family Versus Nonfamily Firms. Journal of Business Ethics, 1-26.

Prommin, P., Jumreornvong, S., \& Jiraporn, P. (2014). The effect of corporate governance on stock liquidity: The case of Thailand. International Review of Economics and Finance. 32, 132 142.

Pucheta-Martínez, M.C., Bel-Oms, I., Olcina-Sempere, G. (2016).Corporate governance female directors and quality of financial information. Journal of Business Ethics, 25 (4), 363-385.

Rose, C. (2007). Does female board representation influence firm performance? The Danish evidence. Corporate Governance: International Review 15(2), 404-413.

Singh, V. and Vinnicombe S. (2004). Why So Few Women Directors in Top UK Boardrooms? Evidence and Theoretical Explanations. Corporate Governance: International Review 12(4), 479-488.

Singh, V., Terjesen S., and Vinnicombe S. (2008). Newly appointed directors in the boardroom : How do women and Man differ?" European Management Journal 26(1), 48-58 